\title{
Cognitive Work Analysis: New Dimensions
}

\author{
Catherine Burns \\ Department of Systems Design Engineering, University of Waterloo, Waterloo Canada \\ catherine. burns @uwaterloo.ca
}

\begin{abstract}
Cognitive work analysis (CWA) originated in the late 1970's and 1980's through the work of Jens Rasmussen, being collected and built into an effective methodology through the 1990's work of Kim Vicente, and culminating in his book Cognitive Work Analysis [1]. Since that time, CWA, and in particular its derivative design approach Ecological Interface Design (EID), has been widely applied in a vast range of complex, control-oriented systems. Since the 1990's however, there has been an explosion of a new type of system networked and distributed systems. These systems are characterized by their highly social dimension, resulting in new challenges in team problem solving, community building, and trust allocation across distributed teams. Our recent work in CWA has focused on adapting CWA to face these new challenges and provide a solution that fits a truly social technical system.
\end{abstract}

Keywords: cognitive work analysis, interface design, task analysis, humancomputer interaction.

\section{Introduction}

In 1999, Vicente published his seminal book, Cognitive Work Analysis (CWA) [1]. This book brought together several analytical views of cognitive work that had been developed earlier by Jens Rasmussen and his associates at the Riso National Laboratory in Denmark [2-4]. The application of CWA as a method was demonstrated through the use of the method on a sample experimental process control system, DURESS [5]. DURESS was later used through multiple studies to confirm and to test the principles of CWA and Ecological Interface Design. While DURESS served as a solid test bed for validating the new approach, DURESS had limitations due to its simplicity compared to real world systems. In particular, DURESS could be operated with a single operator, and with relatively low competency levels, which meant that while this system could demonstrate the first three phases of CWA, Work Domain Analysis (WDA), Control Task Analysis (ConTA) and Strategies Analysis (StA), it remained a weak example for the last two phases, Social Organizational Analysis (SOA) and Worker Competency Analysis (WCA) [1].

For many years, as CWA was becoming more established, this pattern continued. Multiple researchers demonstrated WDA, ConTA and in some cases StA, gradually refining these methods, making them simpler and building a set of examples [6,7]. These first three phases were also demonstrated in design, showing that they could

P. Campos et al. (Eds.): HWID 2012, IFIP AICT 407, pp. 1-11, 2013.

(C) IFIP International Federation for Information Processing 2013 
effectively define useful design requirements and develop designs that were often more effective than existing designs. Essentially, through time, the value proposition for using CWA as a method became more convincing as more examples and designs emerged. In the background, however, the two final phases of CWA languished with little attention and poor development. In many cases, researchers made cursory statements that "of course" systems operated in a social-organizational context and "of course" the business would ensure workers had adequate competencies to operate the design. It was assumed, in fact, that in most cases, social-organizational factors, and worker competencies were out of the scope of the designer and were essentially elements of context that could not be changed.

Behind the scene, however, the world was changing. In 2002 LinkedIn was created and in 2004 Facebook was started. While it would be several years before these sites had become established, the reality was that the technology of social connectivity had

arrived. Social connectivity meant that quick and fast access to people, as well as the development of new flexible social structures in the form of social networks. Social networks began among groups of friends but before long the business world had also adopted chats and social groups. Social networking allowed for faster and more flexible teamwork, mentoring and the rich access to expertise. Even a plant operator worked in a team, had email and chat to others in his or her organization, and talked to other operators and colleagues in his or her profession. Social organizational factors were becoming more important.

Early attempts to apply CWA to team situations produced a variety of results. Hadjukiewicz et al. [8] mapped work domain zones in the operating room. We adopted this for a multiple objective domain in a military context [9]. Naikar developed the contextual activity template as an approach for teams [10,11] and Jenkins and Stanton showed various team roles across different phases of CWA [12]. Through this work it became apparent that as CWA tackled social questions, a variety of approaches would be needed. We decided to focus on the development of a range of CWA inspired social methods to help tackle these new questions. We identified different needs for teams and for communities. In this paper we are defining teams as relatively small, goal focused work teams. In contrast communities are larger, more open, and less tightly focused. Team CWA is discussed first and in the following section, community based CWA is discussed. While Team CWA is fairly well developed, we are just beginning to explore CWA for community-based design.

\section{Team CWA}

Several Team CWA as an approach recognizes that in many cases, people do not work in isolation but function with others to achieve goals. In designing systems for teams, many questions arise such as "what view should team leaders have of team member work?" "What do people need to know of each other's work" and "how do we facilitate effective communication between team members?". Traditional CWA as a base provides a useful structure for gathering requirements, but does not particularly 
lead analysts towards developing the models or exploring the requirements that would answer these questions.

In developing Team CWA, we quickly realized that team concerns influenced all levels of the analysis and could not be easily reduced to a single analysis phase [13]. In fact, isolating team requirements from the primary CWA could be ineffective and lead to a loss of information. We argue that, when design for a team is required, that team requirements can be handled through the traditional CWA phases with some modifications. We suggest a full four phases looking at team WDA, team ConTA, team StrA, and team Competency Analysis (Figure 1). In the next sections these phases are described, in the context of a healthcare example taken from [13].

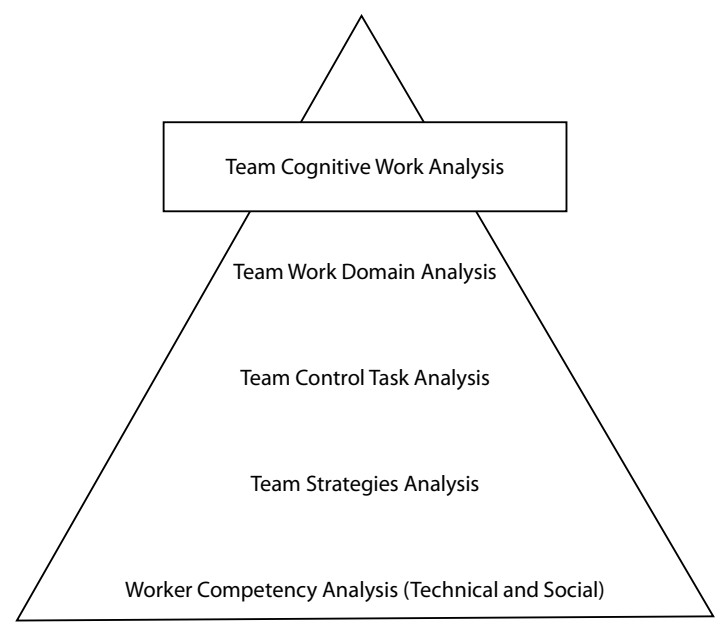

Fig. 1. Team CWA

The basics of the team CWA analyses are discussed below.

\subsection{Team Work Domain Analysis}

The objective of Team WDA is to understand how work domain constraints influence a team. There are several distinct possibilities:

1. Team members may have shared objects or processes.

2. Team members may have objects or processes that are not shared.

3. Team members may have shared purposes.

4. Team members may have different or conflicting purposes.

When team members have their own individual scope of control that is distinct from others, team work is relatively simple. However, when team members share objects or processes, team relevant design requirements become important. Must team members share object $\mathrm{x}$ ? or pass it between them? Do they use it for different purposes? Do they have different information needs from object $\mathrm{x}$ ? Similarly, which team members have 
shared purposes? And which team members may have conflicting purposes? Team members with shared purposes may find it useful to see how they are each contributing to the shared goal, while team members with conflicting purposes may need to accommodate each other to achieve overall success. Team members with individual and unshared purposes may need to focus on their own part of the work domain, with less distraction from the team. Using a basic WDA, team WDA can use maps of team member zones on the work domain, contextual activity templates, or collaboration tables to keep track of various team interactions in the work domain. Below (Figure 2) we show an example of mapped zones in a healthcare domain.

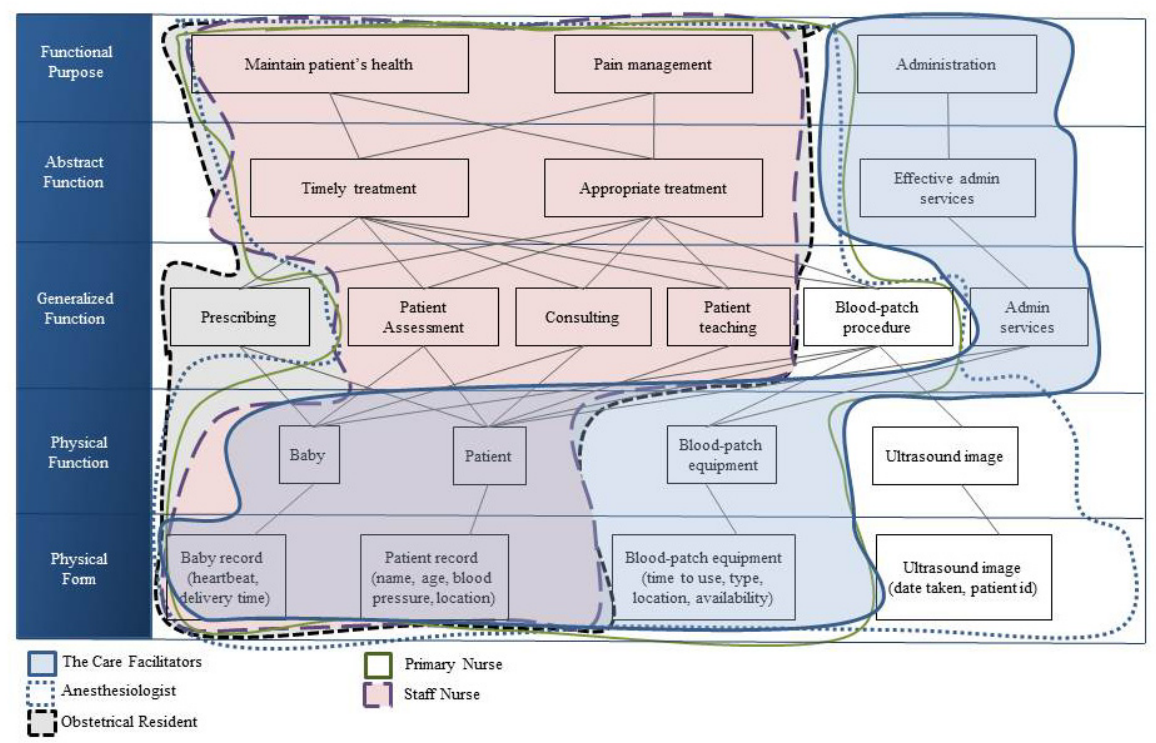

Fig. 2. Team member mappings on a work domain model

\subsection{Team Control Task Analysis}

Team ConTA should identify how control tasks are shared across team members. It is also an opportunity to identify when various team collaborate on tasks synchronously, or across time, asynchronously. The contextual activity template can be used for this, multiple decision ladders, and we have recently explored the development of a decision wheel (Figure 3). The decision wheel has some advantages in showing individual team members as slices and separate teams as wheels. As well, the wheel tends to concentrate the evaluation processes into the bulls-eye, helping to identify key team members involved in more complex decision-making. We have also used this structure to show synchronous and asynchronous activity. Sample wheels are shown in Figure 3. 


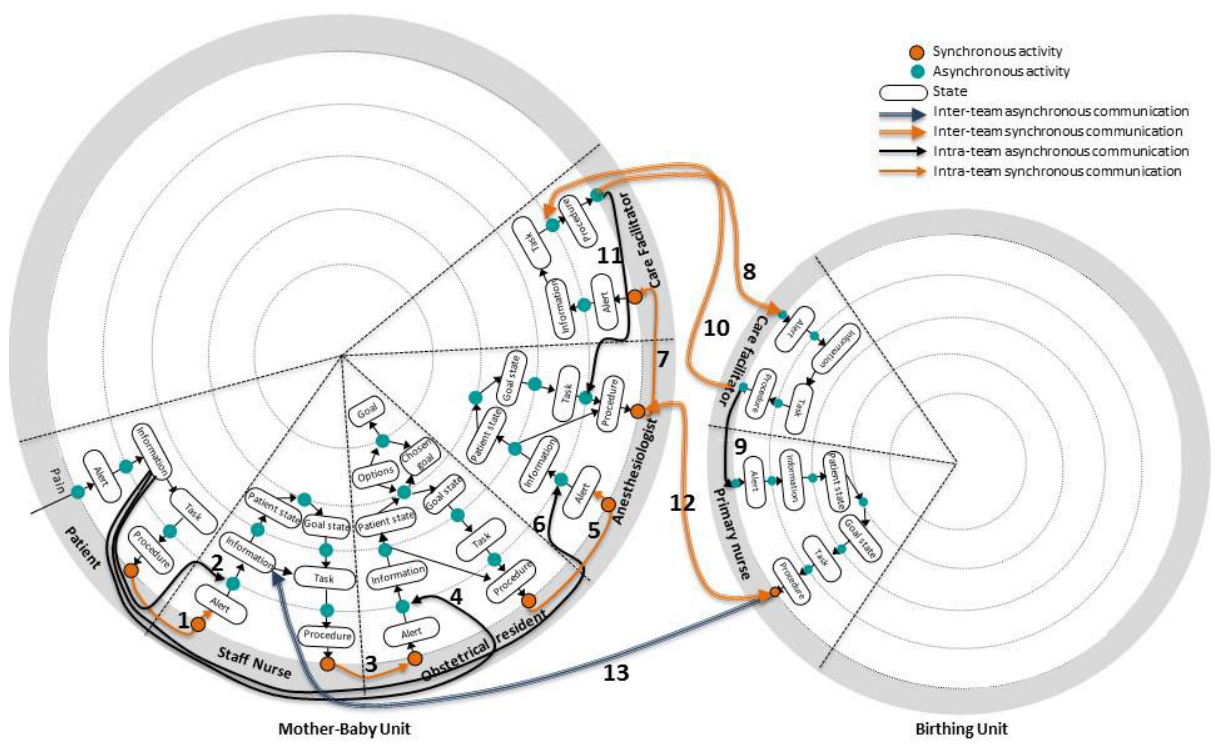

Fig. 3. The decision wheel (from Ashoori and Burns, Journal of Cognitive Engineering and Decision Making in press), copyright (C2012 Human Factors and Ergonomics Society. Reprinted by Permission of SAGE Publications.

\subsection{Team Strategies}

Strategies, in CWA are alternative ways of achieving control tasks. While we see individual strategies shift with factors like expertise and workload, we also see teams show strategies. To respond to different work constraints, teams may adopt different configurations, roles, and expertise levels. The example below in Figure 4 shows different team structures under normal and emergency situations in the mother-baby unit example. Note that in emergency situations, the team shifts to highly experienced personnel, different types of expertise, and has access to different resources.

\begin{tabular}{|l|l|l|l|l|l|l|l|}
\hline Situation & $\begin{array}{l}\text { Team Struc- } \\
\text { ture }\end{array}$ & $\begin{array}{l}\text { Resource } \\
\text { Access }\end{array}$ & $\begin{array}{l}\text { Expertise } \\
\text { Level }\end{array}$ & $\begin{array}{l}\text { Task } \\
\text { Priority }\end{array}$ & Location & Duration & $\begin{array}{l}\text { Systems } \\
\text { used }\end{array}$ \\
\hline Emergency & $\begin{array}{l}\text { Paediatrician } \\
\text { Staff nurse } \\
\text { Obstetrical } \\
\text { resident } \\
\text { Anaesthesi- } \\
\text { ologist } \\
\text { Primary nurse }\end{array}$ & $\begin{array}{l}\text { Full } \\
\text { access }\end{array}$ & Expert & High & $\begin{array}{l}\text { Mother- } \\
\text { baby unit } \\
\text { with } \\
\text { transfer as } \\
\text { needed }\end{array}$ & $\begin{array}{l}\text { Quick } \\
\text { response }\end{array}$ & $\begin{array}{l}\text { Electronic } \\
\text { patient } \\
\text { record and } \\
\text { others }\end{array}$ \\
& & & & & & \\
\end{tabular}

Fig. 4. Team strategies 


\begin{tabular}{|l|l|l|l|l|l|l|l|}
\hline Normal & $\begin{array}{l}\text { Staff Nurse } \\
\text { Obstetrical } \\
\text { resident } \\
\text { Anaesthesi- } \\
\text { ologist } \\
\text { Primary nurse }\end{array}$ & $\begin{array}{l}\text { Limited } \\
\text { access }\end{array}$ & $\begin{array}{l}\text { Novice } \\
\text { and expert }\end{array}$ & Medium & $\begin{array}{l}\text { Mother- } \\
\text { baby unit }\end{array}$ & $\begin{array}{l}5-10 \text { min- } \\
\text { utes }\end{array}$ & $\begin{array}{l}\text { Electronic } \\
\text { patient } \\
\text { record }\end{array}$ \\
\end{tabular}

Fig. 4. (Continued)

In general, there are different kinds of strategies that can be modeled through CWA strategy analysis, from structural strategies provided by the work domain itself, team development strategies, operational strategies, and coordination strategies. The team strategies in this example are a case of coordination strategies.

\subsection{Social Competencies}

Where worker competencies would define the skills, rules and knowledge needed for an operator to perform their job, social competencies define the skills and capabilities needed in various team roles. Some team members need to provide leadership, some mentorship, some negotiation, and others need to take direction and understand objectives. In the next two tables, we include the worker competencies (Table 1) and the social competencies (Table 2) from the mother-baby unit observations. It is clear from this example, that different social capabilities are required for different roles and an incorrect assignment of people to roles could significantly affect the coordination and performance of the team.

Table 1. Worker competencies

\begin{tabular}{|c|c|c|c|}
\hline Actions & Skill-based behavior & Rule-based behavior & $\begin{array}{c}\text { Knowledge-based } \\
\text { behavior }\end{array}$ \\
\hline $\begin{array}{l}\text { Collecting } \\
\text { information }\end{array}$ & $\begin{array}{l}\text { An experienced } \\
\text { obstetrical resident } \\
\text { should be aware of } \\
\text { the symptoms and } \\
\text { know what signs and } \\
\text { symbols to observe. }\end{array}$ & $\begin{array}{l}\text { The obstetrical } \\
\text { resident should be } \\
\text { able to look up the } \\
\text { fact sheets or best } \\
\text { practices to find a list } \\
\text { of signs and symbols } \\
\text { to observe. }\end{array}$ & $\begin{array}{l}\text { The obstetrical resident } \\
\text { should be able to analyze } \\
\text { the symptoms and plan } \\
\text { for further assessments, } \\
\text { if required. }\end{array}$ \\
\hline $\begin{array}{l}\text { Identifying } \\
\text { the reason for } \\
\text { the pain }\end{array}$ & $\begin{array}{l}\text { An experienced } \\
\text { obstetrical resident } \\
\text { should know that a } \\
\text { lumbar puncture can } \\
\text { cause a headache. }\end{array}$ & $\begin{array}{l}\text { The obstetrical } \\
\text { resident should be } \\
\text { able to look up the } \\
\text { fact sheets, best } \\
\text { practices, or } \\
\text { instructions to find } \\
\text { the cause for a post- } \\
\text { dural puncture } \\
\text { headache. }\end{array}$ & $\begin{array}{l}\text { Severe headache on the } \\
\text { day of surgery can have } \\
\text { many reasons. The } \\
\text { obstetrical resident } \\
\text { should be able to analyze } \\
\text { supplementary } \\
\text { information and make a } \\
\text { decision about the cause } \\
\text { of the headache. }\end{array}$ \\
\hline
\end{tabular}


Table 1. (Continued)

\begin{tabular}{|c|c|c|c|}
\hline $\begin{array}{l}\text { Consulting } \\
\text { with the rest } \\
\text { of the team to } \\
\text { verify that } \\
\text { reason and } \\
\text { discuss } \\
\text { possible } \\
\text { prescriptions }\end{array}$ & $\begin{array}{l}\text { An experienced } \\
\text { obstetrical resident } \\
\text { should know the best } \\
\text { person to get opinion } \\
\text { from. He should know } \\
\text { what sort of } \\
\text { information should be } \\
\text { provided for effective } \\
\text { discussion. }\end{array}$ & $\begin{array}{l}\text { The obstetrical } \\
\text { resident should be } \\
\text { aware of the fact } \\
\text { sheets and the best } \\
\text { practices and be able } \\
\text { to discuss them with } \\
\text { the peers. }\end{array}$ & $\begin{array}{l}\text { The obstetrical resident } \\
\text { should be able to } \\
\text { effectively describe the } \\
\text { observation, discuss the } \\
\text { options with the peer, } \\
\text { analyze the situation, and } \\
\text { make a decision about } \\
\text { the reason for the pain. }\end{array}$ \\
\hline
\end{tabular}

Table 2. Social competencies

\begin{tabular}{|l|l|l|}
\hline Function Role & Team role & Social skills required (Belbin,1981) \\
\hline $\begin{array}{l}\text { Care facilitator } \\
\text { at MBU }\end{array}$ & Coordinators & $\begin{array}{l}\text { Mature, confident, a good chairperson, should be } \\
\text { able to clarify goals, promote decision making, and } \\
\text { delegate well }\end{array}$ \\
\cline { 1 - 2 } $\begin{array}{l}\text { Care facilitator } \\
\text { at BU }\end{array}$ & Team-workers & $\begin{array}{l}\text { Cooperative, perceptive and diplomatic. Should be } \\
\text { able to listen, build, and avert friction }\end{array}$ \\
\cline { 1 - 2 } Primary nurse & Specialists & $\begin{array}{l}\text { Single-minded, self-starting, dedicated to providing } \\
\text { knowledge and skills in rare supply }\end{array}$ \\
\cline { 1 - 2 } Staff nurse & Anesthesiologist & $\begin{array}{l}\text { Obstetrical } \\
\text { resident }\end{array}$
\end{tabular}

\section{CWA in Communities}

While improving CWA for teams is effective for smaller, more goal directed situations, there are cases where one can be asked to develop new designs for larger communities. Designing for communities can be a challenge as there are very few human factors methods that suit these kinds of problems. To work with CWA in communities, we explored community of practice concepts (CoP) [14]. The CoP ideas originate from the work of Wenger [15] and seek to understand why communities exist and how they grow. A difficulty with using the CoP concepts is that they were never developed for design. In the example below we show the use of CoP concepts in WDA. In this case, we were designing a social networking environment for a development organization. The key to CWA in community contexts is realizing that while a community has goals (in this case meeting certain development goals, the left hand column of the WDA in Table 3), a community also has a need to build and sustain itself as an entity (the right hand column of the WDA in Table 3). The CoP concepts were very helpful in understanding community-building requirements. In this sense, and in the terminology of WDA, a community has purposes, values and principles, processes, and people working together. Note that it can be helpful in this context to adjust the labels of the WDA to fit with more community relevant terms. 
Table 3. Work domain analysis including community domain elements (Euerby, Burns Journal of Cognitive Engineering and Decision Making 6 (2), 194-213. (c) 2012 by Human Factors and Ergonomics Society. Reprinted by Permission of SAGE publications.

\begin{tabular}{|c|c|c|c|}
\hline & Domain & Community & \\
\hline Functional Purpose & $\begin{array}{l}\text { Achieve the UN Millen- } \\
\text { nium Development } \\
\text { Goals (MDGs) }\end{array}$ & $\begin{array}{l}\text { Agreed upon role in the } \\
\text { larger context; Strength } \\
\text { in relationships to active- } \\
\text { ly discuss differences } \\
\text { with respect to the do- } \\
\text { main and practice; } \\
\text { Established what know- } \\
\text { ledge should be shared } \\
\text { and how to share it. }\end{array}$ & $\begin{array}{l}\text { Desired State of the } \\
\text { Learning Community }\end{array}$ \\
\hline $\begin{array}{l}\text { Value and Priority } \\
\text { Measures }\end{array}$ & $\begin{array}{l}\text { Span of the external } \\
\text { network vs. strength of } \\
\text { the connections; } \\
\text { Social action vs. research } \\
\text { results; } \\
\text { Power of the researcher } \\
\text { vs. power of the com- } \\
\text { munities. } \\
\text { Mobilize knowledge and } \\
\text { mobilize communities; } \\
\text { Bring awareness about } \\
\text { MDGs and impel collec- } \\
\text { tive social action toward } \\
\text { their achievement; } \\
\text { Educate, engage and } \\
\text { empower communities. }\end{array}$ & $\begin{array}{l}\text { Participation vs. reifica- } \\
\text { tion; } \\
\text { Designed vs. emergent; } \\
\text { Identification vs. nego- } \\
\text { tiability; } \\
\text { Local vs. global. } \\
\text { Increase alignment, en- } \\
\text { gagement and imagina- } \\
\text { tion. }\end{array}$ & $\begin{array}{l}\text { Tradeoffs and Priori- } \\
\text { ties of the Negotiation } \\
\text { of Meaning }\end{array}$ \\
\hline Processes & $\begin{array}{l}\text { Building formal partner- } \\
\text { ships, hosting network- } \\
\text { ing and public outreach } \\
\text { events, collaborating } \\
\text { with partners. }\end{array}$ & $\begin{array}{l}\text { Building connections } \\
\text { between the core partici- } \\
\text { pants, identifying oppor- } \\
\text { tunities to provide value } \\
\text { in the larger context, } \\
\text { finding the ideas and } \\
\text { insights that are worth } \\
\text { sharing with other mem- } \\
\text { bers, identifying gaps in } \\
\text { the knowledge, refining } \\
\text { the CoP's role in the } \\
\text { larger context }\end{array}$ & Practices \\
\hline $\begin{array}{l}\text { People, Relationships, } \\
\text { Projects, Events }\end{array}$ & \multicolumn{2}{|c|}{$\begin{array}{l}\text { Network Facilitator, Executive Team Members, } \\
\text { Regional Coordinators, peripheral members, Know- } \\
\text { ledge Partners, Organizational Partners, Memoran- } \\
\text { dums of Agreement with Organizational Partners, } \\
\text { Executive Meetings, Stand-Up Against Poverty } \\
\text { Events, Bridging the World virtual events. }\end{array}$} & $\begin{array}{l}\text { People, Relationships, } \\
\text { Projects, Events }\end{array}$ \\
\hline
\end{tabular}

In this particular case, this analysis was used to redesign a site for the community. Over a six-month longitudinal study, significant improvements in community structure and presence were obtained [16, 17]. This provides early encouragement that this approach to design for communities may be effective. 


\section{Discussion: When to Use What?}

The intention of this work is not to turn CWA into a massive analysis of individual, team and community, multiplied by 4 phases of analysis. But given systems with different needs, CWA needs to provide a responsive methodology to help designers to face these new systems. CWA is a toolbox and while doing every analysis at every level of detail is ideal, it is also unrealistic in many cases.

Designers need to understand the scope of their design problem, its scale, and the key objectives of the redesign. There are many examples of successful designs developed solely from WDA. We have also had strong success using ConTA and StA to inform design in environments like healthcare where work domain information can be difficult to obtain. Just as the traditional phases of WDA can be applied in part to solve a design problem, so too can a more team or community oriented view be adopted if that suits the problem at hand. Figure 5 below provides some guidance on how to choose approaches.

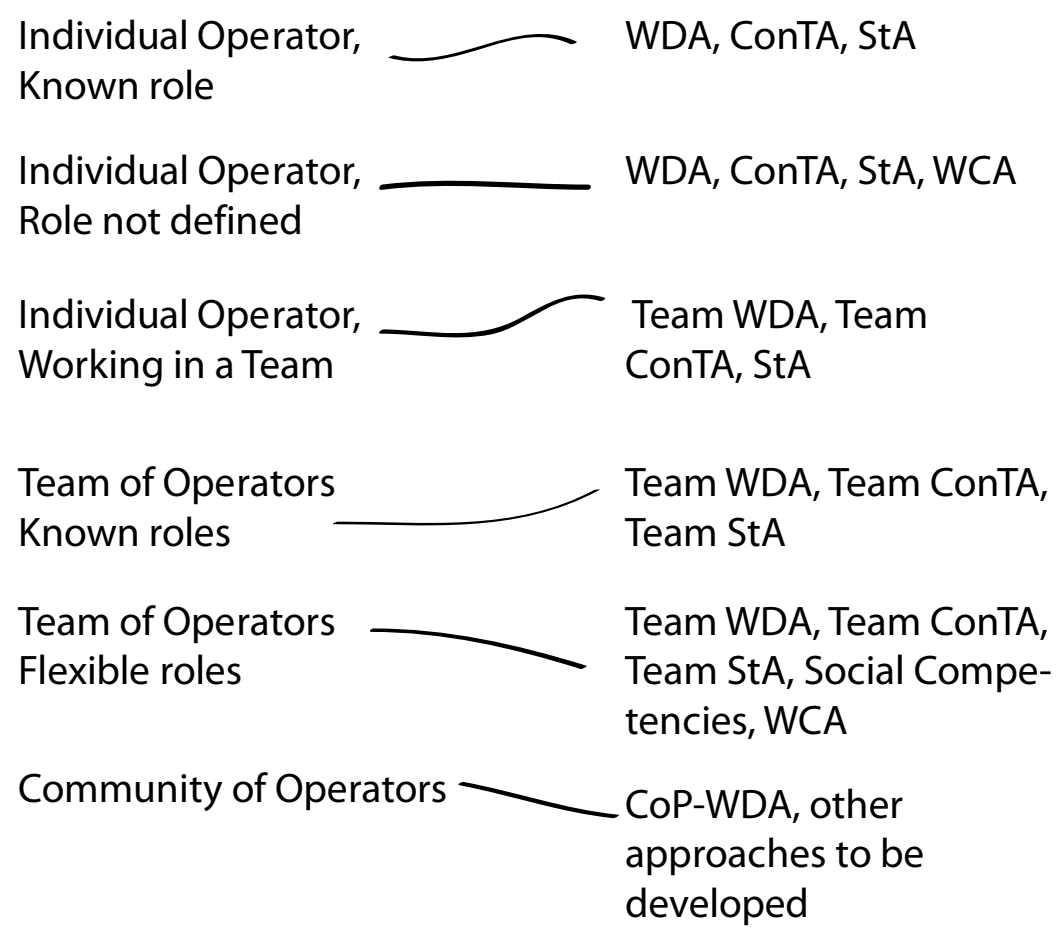

Fig. 5. Choosing CWA approaches

\section{Conclusion: Next Steps}

Evolving CWA, and indeed Human Factors Engineering to tackle modern sociotechnical systems is just beginning. There are, at this point, still relatively few methods 
adapted for social or team systems and few examples. The work presented here is also preliminary, but expected to be a core research direction for the Advanced Interface Design Lab over the next few years. Several key research directions are apparent.

First, further method development is possible. We have not yet integrated the ideas of macro cognition and emergent team processes into CWA and there is evidence that these processes play an important role. Further, the community building approach could be deepened through an understanding of community processes, strategies, and competencies. Completing these directions would provide a rich analytical approach to understanding cognitive work in a variety of environments.

Understanding the design support for these environments is critical. Drawing from a base the ecological psychology foundation of ecological interface design, we anticipate a new class of affordances, social affordances that need to be understood. These affordances already exist, and we use them every day (friend counts, like buttons, mail and chat are just a few), but a systematic understanding of the influence of these affordances and how to best use them in design does not exist. Furthermore, there are social processes such as trust and engagement that are very influential in encouraging, or discouraging human behaviour that are amenable to influence by design but remain poorly understood. We intend over the next few years to explore the design of social affordances as well as how trust and engagement are influenced through design.

Acknowledgments. This work was made possible through an NSERC Discovery Accelerator Supplement Award to Catherine Burns. The Accelerator Supplement Award identifies Canadian researchers who are most likely to become world class researchers and make a lasting impact in their field.

\section{References}

1. Vicente, K.J.: Cognitive Work Analysis, Toward Safe, Productive, and Healthy Computerbased Work. Lawrence Erlbaum Associates, NJ (1999)

2. Rasmussen, J.: Skills, rules, and knowledge; signals, signs, and symbols, and other distinctions in human performance models. IEEE Transactions on Systems, Man, and Cybernetics 13, 257-266 (1983)

3. Rasmussen, J.: The role of hierarchical knowledge representation in decision making and system management. IEEE Transactions on Systems, Man and Cybernetics 15, 234-243 (1985)

4. Rasmussen, J., Jensen, A.: Mental procedures in real-life tasks: A case study of electronic trouble shooting. Ergonomics 17, 293-307 (1974)

5. Vicente, K., Rasmussen, J.: Ecological interface design: Theoretical foundations. IEEE Transactions on Systems, Man and Cybernetics 22, 1-18 (1992)

6. Burns, C.M., Hajdukiewicz, J.R.: Ecological Interface Design. CRC Press, Boca Raton (2004)

7. Bisantz, A.M., Burns, C.M.: Applications of Cognitive Work Analysis. CRC Press, Boca Raton (2008) 
8. Hajdukiewicz, J.R., Vicente, K.J., Doyle, D.J., Milgram, P., Burns, C.M.: Modeling a medical environment: An ontology for integrated medical informatics design. International Journal of Medical Informatics 62, 79-99 (2001)

9. Burns, C.M., Torenvliet, G., Chalmers, B., Scott, S.: Work domain analysis for establishing collaborative work. In: Proceedings of the 53rd Annual Meeting of the Human Factors and Ergonomics Society, pp. 314-318 (2009)

10. Naikar, N., Pearce, B., Drumm, D., Sanderson, M.P.: Designing teams for first-of-a-kind, complex systems using the initial phases of Cognitive Work Analysis: Case study, human factors. Human Factors 45, 202-217 (2003)

11. Naikar, N., Moylan, A., Pearce, B.: Analyzing activity in complex systems with cognitive work analysis: Concepts, guidelines, and case study for control task analysis. Theoretical Issues in Ergonomics Science 7, 371-394 (2006)

12. Jenkins, D.P., Stanton, N.A., Salmon, P.M., Walker, G.H., Young, M.S.: Using Cognitive Work Analysis to explore activity allocation within military domains. Ergonomics 51, 798-815 (2008)

13. Ashoori, M., Burns, C.M.: Team Cognitive Work Analysis: Structure and tasks. Journal of Cognitive Engineering and Decision Making (in press)

14. Euerby, A., Burns, C.M.: Designing for social engagement in online social networks using communities of practice theory and cognitive work analysis: A case study. Journal of Cognitive Engineering and Decision Making 6, 194-213 (2012)

15. Wenger, E.: Communities of practice: Learning, meaning, and identity. Cambridge University Press, Cambridge (1998)

16. Euerby, A., Burns, C.M.: Improving social connection through a communities of practice inspired Cognitive Work Analysis approach. Human Factors (submitted)

17. Euerby, A., Burns, C.M.: Increasing social activity through a Community of Practice inspired design. Advances in Human-Computer Interaction (submitted) 